\title{
PENERAPAN STRUCTURAL EQUATION MODELING PARTIAL LEAST SQUARE PADA KEPUASAN MASYARAKAT TERHADAP PELAYANAN PUBLIK KEPOLISIAN KALIMANTAN BARAT
}

\author{
Titania Aurellia, Hendra Perdana
}

INTISARI

\begin{abstract}
Kritik dan saran masyarakat dalam hal pelayanan, mendorong unit penyelenggara pelayanan publik dituntut untuk memenuhi harapan masyarakat. Masyarakat menilai pelayanan publik yang dilakukan tidak sesuai harapan, sehingga perlunya tindakan yang dapat memperbaiki hal tersebut, jika tidak ditangani dapat menimbulkan ketidakpercayaan dari masyarakat. Salah satu unit penyelenggara pelayanan publik yaitu Kepolisian Daerah Kalimantan Barat yang melakukan survei kepuasan masyarakat terhadap pelayanan publik. Ada beberapa aspek yang menjadi variabel yaitu aspek penegakan hukum $\left(\xi_{1}\right)$, aspek pemeliharaan kamtibmas $\left(\xi_{2}\right)$, aspek pelayanan publik $\left(\xi_{3}\right)$, dan aspek kepercayaan masyarakat $(\eta)$. Metode yang digunakan dalam penelitian ini adalah structural equation modeling partial least square (SEM-PLS), dengan menggunakan SEM-PLS dimungkinkan menggunakan ukuran sampel relatif kecil dan tidak membutuhkan asumsi normalitas. Penelitian ini menggunakan software smartPLS 3.0 dengan penerapan SEM-PLS untuk menganalisis hubungan variabel laten endogen dan variabel laten eksogen. Berdasarkan hasil penelitian yang telah dilakukan, didapatkan model persamaan yaitu $\eta=0,417 \xi_{2}+0,398 \xi_{3}$, dengan variabel yang diperoleh mempengaruhi aspek kepercayaan masyarakat $(\eta)$ secara signifikan adalah variabel aspek pemeliharaan kamtibmas $\left(\xi_{2}\right)$ dan aspek pelayanan publik $\left(\xi_{3}\right)$. Nilai $R^{2}$ untuk model persamaan struktural yaitu sebesar $46,5 \%$.
\end{abstract}

Kata Kunci : Pelayanan Publik, Kepolisian, SEM-PLS

\section{PENDAHULUAN}

Analisis multivariat yaitu berkaitan dengan analisis banyak variabel yang memungkinkan untuk melakukan penelitian terhadap lebih dari dua variabel secara bersamaan [1]. Metode yang mampu menganalisa pola hubungan antara variabel laten dan indikator, variabel laten yang satu dengan lainnya, serta kesalahan pengukuran secara langsung adalah metode structural equation modeling (SEM). Pada umumnya terdapat dua jenis SEM yaitu covariance based structural equation modeling (CB-SEM) dan structural equation modeling partial least square (SEM-PLS). Analisis menggunakan SEM-PLS mengizinkan data dengan sampel kecil dan data tidak harus berdistribusi normal [2]. Seiring dengan kemajuan teknologi dan tuntutan masyarakat dalam hal pelayanan, maka unit penyelenggara pelayanan publik dituntut untuk memenuhi harapan masyarakat dalam melakukan pelayanan. Salah satu upaya Kepolisian Daerah (Polda) Kalimantan Barat sebagai penyelenggara pelayanan publik yaitu melakukan survei kepuasan masyarakat. Hasil dari penelitian ini diharapkan dapat menjadi evaluasi terhadap kinerja Polda Kalimantan Barat sebagai pelaksana pelayanan publik bagi masyarakat. Penelitian ini bertujuan menerapkan SEM-PLS untuk menganalisis hubungan variabel laten endogen dan variabel laten eksogen pada kepuasan masyarakat terhadap pelayanan publik oleh kepolisian Kalimantan Barat. Variabel penelitian tidak memenuhi asumsi normalitas dan memiliki data dengan sampel kecil maka digunakan SEM-PLS. Variabel laten yang digunakan terdiri dari tiga variabel eksogen yaitu aspek penegakan hukum, aspek pemeliharaan kamtibmas dan aspek pelayanan publik. Variabel endogen yang digunakan yaitu aspek kepercayaan masyarakat. 
Penelitian ini menggunakan data survei kepuasan masyarakat terhadap pelayanan publik oleh Polda Kalimantan Barat dengan sampel yang digunakan yaitu sebanyak 100 responden. Tahapan awal pada penelitian ini yaitu melakukan uji validitas instrumen dan reliabilitas instrumen. Data sudah memenuhi uji validitas instrumen apabila nilai $v_{x y}>v_{(\alpha, n-2)}$ dan reliabilitas instrumen apabila nilai cronbach's alpha $>0,6$. Spesifikasi model pada SEM-PLS yaitu dengan merancang inner model dan outer model. Setelah inner model dan outer model dibentuk, selanjutnya mengonstruksi diagram jalur untuk membangun hubungan-hubungan antar variabel laten. Berdasarkan diagram jalur maka dapat dilakukan konversi diagram jalur ke dalam persamaan. Setelah itu dilanjutkan dengan estimasi parameter, nilai parameter dapat diperoleh dari estimasi menggunakan software smartPLS. Evaluasi model pada SEM-PLS yaitu evaluasi hubungan antara variabel laten dan indikator (outer model) dan evaluasi antar variabel laten (inner model). Evaluasi outer model terdapat uji validitas konvergen, validitas diskriminan dan reliabilitas komposit. Setelah setiap uji pada evaluasi outer model terpenuhi, maka dapat dilanjutkan dengan evaluasi inner model. Inner model dalam SEM-PLS dievaluasi menggunakan $\mathrm{R}^{2}$ dan uji signifikansi antar variabel laten dalam inner model.

\section{SPESIFIKASI MODEL SEM-PLS}

Model SEM-PLS digambarkan sebagai berikut [3]:

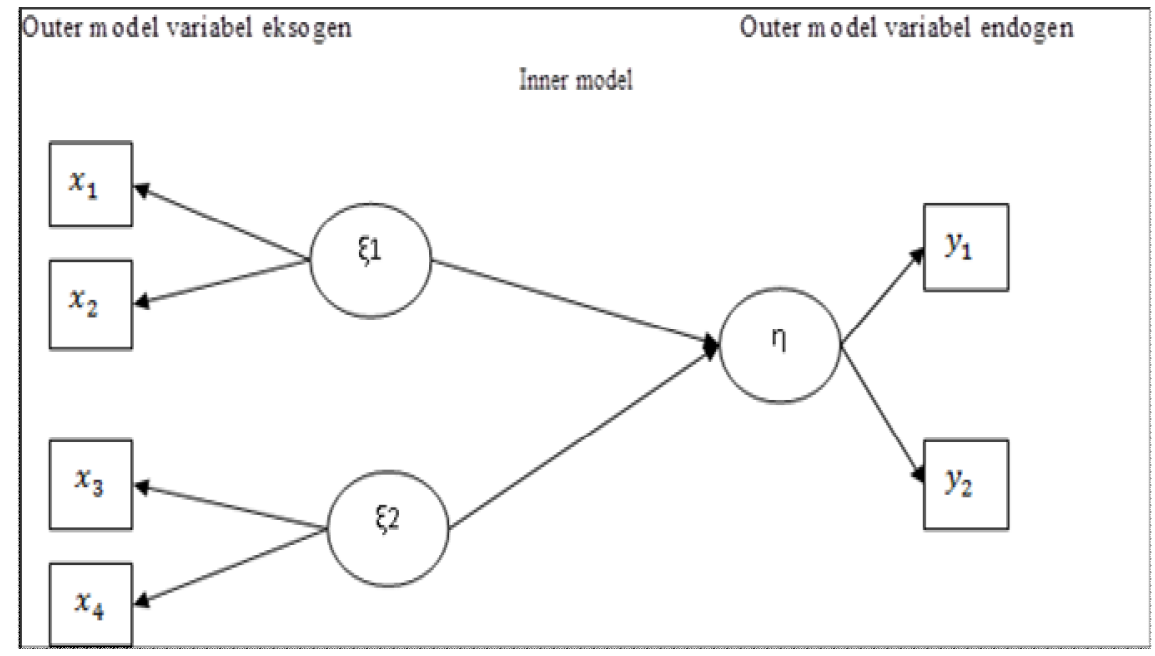

Gambar 1 Model SEM-PLS

Variabel laten yaitu variabel yang tidak dapat diukur secara langsung dan hanya dapat diamati secara tidak langsung melalui variabel teramati (indikator). Pada sebuah model SEM-PLS, variabel laten mempunyai dua jenis yaitu eksogen dan endogen. Variabel eksogen dalam model muncul sebagai variabel bebas pada semua persamaan, sedangkan variabel endogen merupakan variabel terikat yaitu paling sedikit satu persamaan dalam model. Notasi matematik dari variabel laten eksogen adalah $\xi$ (ksi) dan variabel laten endogen $\eta$ (eta) [4]. Variabel teramati (indikator) adalah variabel yang digunakan untuk menjelaskan variabel laten. Indikator yang berkaitan dengan variabel laten eksogen diberi notasi $x$, sedangkan yang berkaitan dengan variabel laten endogen diberi notasi $y$.

SEM-PLS terdapat tiga model yaitu weight relation, outer model, dan inner model. Weight relation menunjukkan nilai estimasi variabel laten, Outer model menunjukkan hubungan antar variabel teramati dengan variabel latennya, dan Inner model menunjukkan hubungan antar variabel laten [5].

1. Weight relation

Weight relation menunjukkan hubungan nilai varian antara indikator dengan variabel latennya. Persamaan untuk weight relation pada variabel laten eksogen yaitu: 


$$
\xi_{j}=\sum_{h=1}^{J} w_{j h} x_{j h}
$$

dimana $h=1,2, \ldots, J, x_{j h}$ adalah indikator ke- $h$ untuk variabel laten ke-j. $w_{j h}$ adalah bobot indikator ke- $h$ untuk variabel laten ke-j yang digunakan untuk mengestimasi variabel laten $\xi_{j}$.

\section{Outer model}

Outer model menggambarkan hubungan antara variabel laten dengan indikatornya. Model refleksif terjadi apabila indikator dipengaruhi oleh variabel laten. Persamaan untuk model indikator refleksif adalah sebagai berikut:

$$
\begin{aligned}
& x_{j}=\lambda_{j} \xi_{j}+\delta_{j} \\
& y_{j}=\lambda_{j} \eta_{j}+\varepsilon_{j}
\end{aligned}
$$

dimana $x_{j}$ adalah indikator variabel laten eksogen untuk variabel laten ke- $j$ dan $y_{j}$ yaitu indikator variabel laten endogen variabel laten ke-j. $\xi_{j}$ adalah variabel laten eksogen, $\eta_{j}$ adalah variabel laten endogen, dengan $\lambda_{j}$ adalah loading factor. $\delta_{j}$ galat pengukuran indikator variabel laten eksogen dan $\varepsilon_{j h}$ galat pengukuran indikator variabel laten endogen.

\section{Inner model}

Inner model menggambarkan model hubungan antar variabel laten yang dibentuk berdasarkan substansi teori. Model persamaan untuk inner model adalah sebagai berikut:

$$
\eta=\sum_{i=1}^{I} \beta_{j i} \eta_{i}+\sum_{b=1}^{B} \gamma_{j b} \xi_{b}+\zeta_{j}
$$

dimana $\beta_{j i}$ adalah koefisien jalur yang menghubungkan variabel laten endogen dengan endogen untuk $i=1,2, \ldots, I$ dan $j$ menyatakan jumlah variabel laten endogen. $\gamma_{j b}$ adalah koefisien jalur yang menghubungkan variabel laten endogen dengan eksogen untuk $b=1,2, \ldots, B, \zeta_{j}$ adalah tingkat kesalahan pengukuran.

\section{KRITERIA PENILAIAN}

SEM-PLS terdapat beberapa evaluasi terhadap inner model dan outer model. Evaluasi outer model dilakukan pengujian validitas konvergen, validitas diskriminan, reliabilitas komposit sebagai berikut:

1. Validitas konvergen

Uji validitas konvergen dalam SEM-PLS dengan indikator refleksif dinilai berdasarkan loading factor. Rule of thumb yang digunakan untuk validitas konvergen adalah outer loading lebih besar dari 0,7 [5].

2. Validitas diskriminan

Penilaian validitas diskriminan adalah dengan nilai average variance extracted (AVE) untuk setiap variabel pada model, nilai AVE yang disarankan yaitu > 0,5 [3]. AVE dapat ditentukan dengan menggunakan perumusan sebagai berikut:

$$
A V E=\frac{\sum_{i=1}^{I} \lambda_{i}^{2}}{\sum_{i=1}^{I} \lambda_{i}^{2}+\sum_{i=1}^{I} \sigma_{\varepsilon_{i}}^{2}}
$$

dimana $i=1,2, \ldots, I$ dengan $\lambda_{i}^{2}$ adalah loading factor ke- $i$ kuadrat dan $\sigma_{\varepsilon_{i}}^{2}$ adalah varians untuk galat ke-i. 
3. Uji reliabilitas komposit

SEM-PLS juga melakukan uji reliabilitas untuk mengukur konsistensi internal alat ukur. Nilai composite reliability harus lebih besar dari 0,7 [5]. Composite reliability dapat ditentukan dengan menggunakan perumusan sebagai berikut:

$$
p c=\frac{\left(\sum_{i=1}^{I} \lambda_{i}\right)^{2}}{\left(\sum_{i=1}^{I} \lambda_{i}\right)^{2}+\sum_{i=1}^{I} \sigma_{\varepsilon_{i}}^{2}}
$$

dimana $i=1,2, \ldots, I$ dengan $\lambda_{i}$ adalah loading factor ke- $i$ dan $\sigma_{\varepsilon_{i}}^{2}$ adalah varians untuk galat ke- $i$.

Evaluasi inner model yaitu dilakukan uji $R$-squared $\left(\mathrm{R}^{2}\right)$ dan uji signifikansi sebagai berikut:

1. $R$-squared $\left(\mathrm{R}^{2}\right)$

Inner model dalam SEM-PLS dievaluasi menggunakan $\mathrm{R}^{2}$ untuk konstruk laten eksogen. Nilai $\mathrm{R}^{2}$ digunakan untuk mengukur tingkat variasi perubahan variabel laten eksogen terhadap variabel laten endogen. Semakin tinggi $\mathrm{R}^{2}$ berarti semakin baik model prediksi dari model penelitian yang diajukan. Namun, $\mathrm{R}^{2}$ bukanlah parameter absolut dalam mengukur ketepatan model prediksi karena dasar hubungan teoritis adalah parameter yang paling utama untuk menjelaskan hubungan kausalitas tersebut [2].

2. Uji signifikansi

Uji signifikansi bertujuan untuk mengetahui besar pengaruh variabel laten eksogen terhadap variabel laten endogen. Nilai signifikansi dapat diperoleh dengan prosedur bootstrapping. Perumusan hipotesis null pada uji signifikansi adalah variabel laten eksogen tidak berpengaruh secara signifikan terhadap variabel laten endogen. Statistik uji yang digunakan adalah [6]:

$$
T_{\text {statistic }}=\frac{b_{j}}{s\left(b_{j}\right)}
$$

dimana $b_{j}$ menyatakan nilai taksiran untuk $\gamma_{j}$, dengan $\gamma_{j}$ koefisien pengaruh variabel eksogen ke-j terhadap variabel endogen. $s\left(b_{j}\right)$ menyatakan standar error untuk $b_{j}$. Kriteria pengujiannya yaitu dengan taraf signifikansi $H_{0}$ ditolak apabila $T_{\text {statistic }}>T_{\text {tabel }}$.

\section{STUDI KASUS}

- Penelitian ini menggunakan data sekunder, yaitu data yang telah dikumpulkan pada kegiatan survei oleh Polda Kalimantan Barat. Proses identifikasi data digunakan software SPSS 20 dan SmartPLS 3.0 dengan jumlah sampel yang digunakan sebanyak 100. Terdapat empat aspek yang dianalisis, diantaranya aspek penegakan hukum dengan terdiri dari 12 indikator, aspek pemeliharaan kamtibmas 14 indikator, aspek pelayanan publik 15 indikator, serta aspek kepercayaan masyarakat tiga indikator.

Tahapan awal sebelum melakukan analisis SEM-PLS adalah pengujian validitas dan reliabilitas instrumen. Pengujian validitas digunakan untuk mengukur valid tidaknya suatu instrumen dengan mencari koefisien korelasi antara skor item dan skor total item dari setiap indikator. Kriteria pengujian yaitu suatu instrumen dikatakan valid apabila $v_{x y}>v_{(0,05 ; 98)}$. Pada penelitian ini menunjukkan seluruh indikator memenuhi kriteria pengujian, sehingga semua indikator penelitian adalah valid. Kemudian, pengujian reliabilitas digunakan untuk menunjukkan tingkat konsistensi dan stabilitas alat ukur. Kriteria pengujian yaitu nilai cronbach's alpha > 0,6 maka kuesioner dinyatakan reliabel. 
Uji reliabilitas pada penelitian ini menunjukkan masing-masing variabel laten mempunyai nilai cronbach's alpha > 0,6 sehingga dapat dikatakan sudah reliabel.

Tahapan selanjutnya setelah uji validitas dan reliabilitas instrumen adalah perancangan inner model dan outer model. Perancangan yaitu dengan empat variabel laten terdiri dari tiga variabel eksogen yaitu aspek penegakan hukum $\left(\xi_{1}\right)$, aspek pemeliharaan kamtibmas $\left(\xi_{2}\right)$ dan aspek pelayanan publik $\left(\xi_{3}\right)$ dengan satu variabel endogen yaitu aspek kepercayaan masyarakat $(\eta)$. Inner model menggambarkan model hubungan antar variabel laten, sedangkan outer model menggambarkan hubungan antara variabel laten dengan indikator. Setelah inner model dan outer model dirancang, selanjutnya yaitu konstruksi diagram jalur dapat dilihat pada Gambar 2.

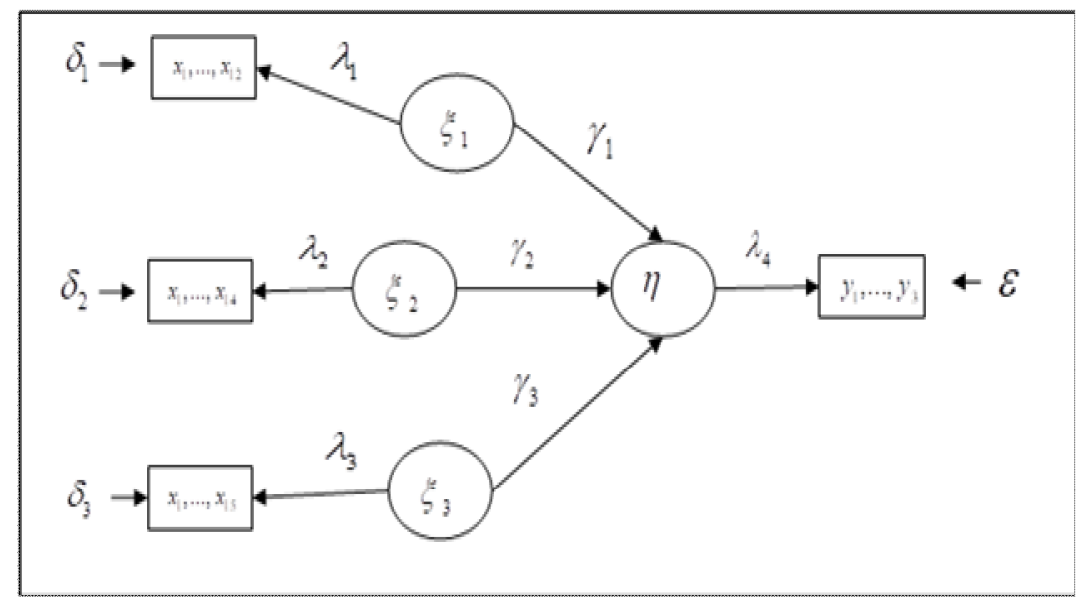

Gambar 2 Konstruksi diagram jalur

Konstruksi diagram jalur telah dilakukan, proses selanjutnya yaitu konversi diagram jalur ke persamaan inner model dan outer model.

1. Inner Model

$$
\eta=\gamma_{1} \xi_{1}+\gamma_{2} \xi_{2}+\gamma_{3} \xi_{3}+\zeta
$$

2. Outer Model

Variabel laten eksogen satu, eksogen dua, eksogen tiga, dan endogen.

$$
\begin{aligned}
& x_{1}=\lambda_{x_{1}} \xi_{x_{1}}+\delta_{x_{1}} \\
& x_{2}=\lambda_{x_{2}} \xi_{x_{2}}+\delta_{x} \\
& x_{3}=\lambda_{x_{3}} \xi_{x_{3}}+\delta_{x_{3}} \\
& y_{1}=\lambda_{y_{1}} \eta_{y_{1}}+\varepsilon_{y_{1}}
\end{aligned}
$$

Berdasarkan perancangan inner model dan outer model serta konstruksi diagram jalur yang telah dibuat yaitu terdapat parameter, nilai dari parameter-parameter yang ada di dalam model dapat diperoleh menggunakan estimasi parameter. Hasil estimasi parameter diperoleh menggunakan software Smart-PLS dapat dilihat pada Gambar 3. Evaluasi pada outer model terdiri dari tiga tahap yaitu uji validitas konvergen, validitas diskriminan dan reliabilitas komposit, sedangkan inner model dievaluasi menggunakan $\mathrm{R}^{2}$. Pada Gambar 3 dengan hasil estimasi awal akan dilakukan evaluasi outer model dan inner model terlebih dahulu sebelum didapat model persamaan. Pada uji validitas kovergen terdapat empat indikator yang memberikan nilai dibawah nilai yang disarankan yaitu 0,7. 
Pada Gambar 3 indikator yang tidak memenuhi validitas konvergen harus dieliminasi dari model. Setelah uji validitas konvergen, dilanjutkan dengan uji validitas dikriminan. Pada indikator perlu dilakukan pengujian validitas dengan melihat nilai AVE, nilai yang disarankan adalah diatas 0,5 . Nilai AVE semua variabel yang terdapat pada model penelitian diatas 0,5 . Sehingga dapat dikatakan bahwa model telah memenuhi validitas diskriminan. Hasil evaluasi model dapat dilihat pada Gambar 4.

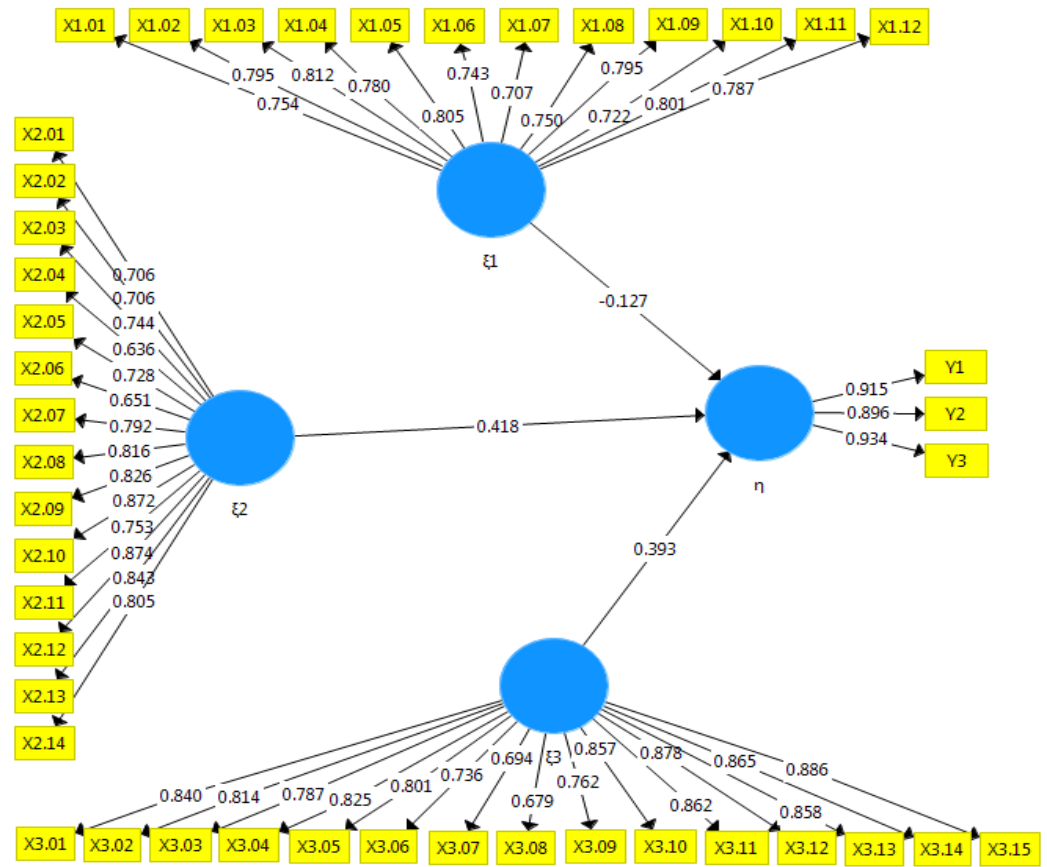

Gambar 3 Hasil Estimasi Parameter

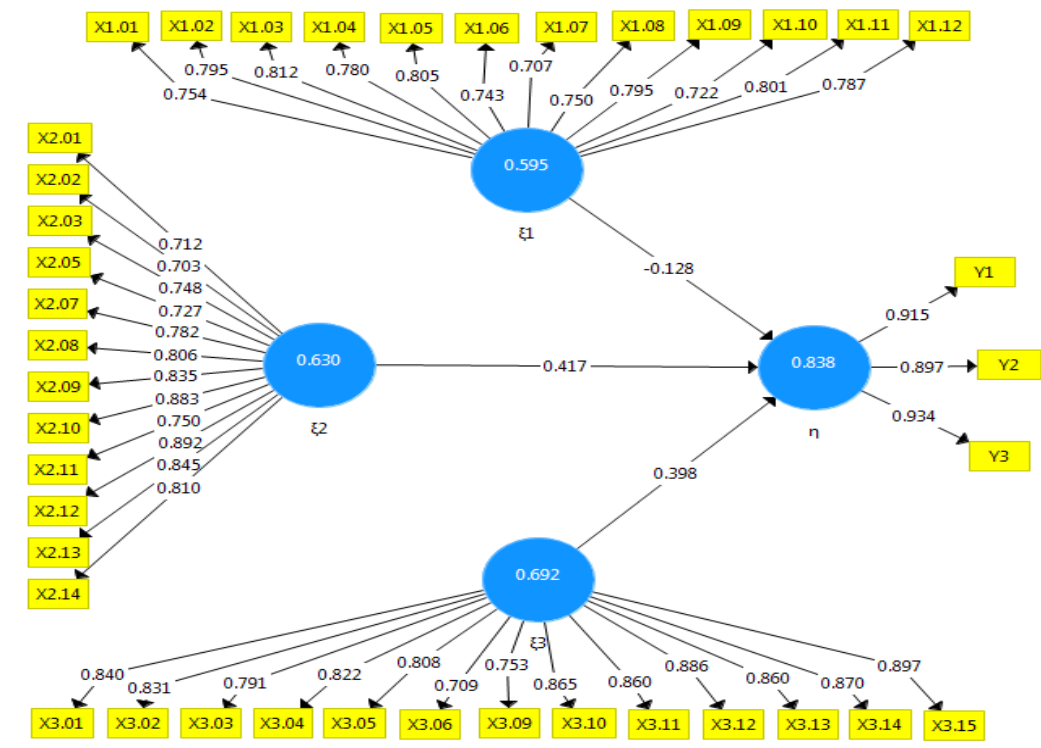

\section{Gambar 4 Hasil Evaluasi}

Pada uji reliabilitas komposit, variabel laten dapat dikatakan mempunyai realibilitas yang baik apabila nilai composite reliability lebih besar dari 0,7. Uji reliabilitas akan menguji masing-masing reliabilitas variabel laten. Nilai composite reliability pada seluruh variabel laten dalam penelitian, menunjukkan nilai yang lebih besar dari 0,7 sehingga dapat dikatakan bahwa semua variabel laten reliabel. 
Setelah evaluasi outer model dilakukan, maka dapat dilanjutkan dengan evaluasi inner model. Evaluasi inner model pada SEM-PLS dilakukan dengan uji $\mathrm{R}^{2}$ dan uji signifikansi. Nilai $\mathrm{R}^{2}$ digunakan untuk mengukur seberapa besar pengaruh variabel laten eksogen terhadap variabel laten endogen. Nilai estimasi untuk hubungan jalur dalam inner model digunakan untuk mengetahui signifikansi dari hubungan-hubungan antar variabel laten. Pengujian hipotesis dengan metode SEM-PLS dilakukan dengan proses bootstrapping dengan software SmartPLS, dapat dilihat hasil pada Tabel 1.

\section{Tabel 1 Hasil bootstrapping}

\begin{tabular}{cccc}
\hline Variabel & $\begin{array}{c}\text { Original } \\
\text { Sample }\end{array}$ & T-Statistic & Kesimpulan \\
& Estimate & & \\
\hline Aspek penegakan hukum $\rightarrow$ Aspek kepercayaan masyarakat & $-0,128$ & 0,954 & Tidak Signifikan \\
Aspek pemeliharaan kamtibmas $\rightarrow$ Aspek kepercayaan masyarakat & 0,417 & 2,812 & Signifikan \\
Aspek pelayanan publik $\rightarrow$ Aspek kepercayaan masyarakat & 0,398 & 2,781 & Signifikan \\
\hline
\end{tabular}

Berdasarkan Tabel 1 diketahui bahwa nilai negatif pada original sample estimate artinya adalah semakin baik kondisi aspek penegakan hukum maka aspek kepercayaan masyarakat akan menurun. Nilai positif pada original sample estimate artinya adalah semakin baik kondisi aspek pemeliharaan kamtibmas dan aspek pelayanan publik maka aspek kepercayaan masyarakat akan meningkat. $T$ statistic untuk variabel aspek penegakan hukum $\left(\xi_{1}\right)$ terhadap variabel aspek kepercayaan masyarakat ( $\eta$ ) sebesar 0,954 . Nilai ini lebih kecil dibandingkan dengan nilai $T_{(\alpha ; n-k-1)}$ dengan $(\alpha)$ sebesar $5 \%$ dan $(n-k-1)=96$ yaitu sebesar 1,985. Dengan demikian hipotesis $n u l l$ diterima sehingga variabel laten aspek penegakan hukum $\left(\xi_{1}\right)$ dengan indikator-indikatornya tidak signifikan berpengaruh terhadap variabel laten aspek kepercayaan masyarakat $(\eta)$. Kemudian pada aspek pemeliharaan kamtibmas $\left(\xi_{2}\right)$ dan aspek pelayanan publik $\left(\xi_{3}\right)$ berpengaruh terhadap variabel aspek kepercayaan masyarakat $(\eta)$ karena masing-masing nilai $T$-statistic lebih besar dari nilai $T$-tabel. Nilai $\mathrm{R}^{2}$ untuk model persamaan struktural yaitu sebesar 0,465 yang mengindikasikan bahwa aspek kepercayaan masyarakat dapat dijelaskan oleh aspek pemeliharaan kamtibmas dan aspek pelayanan publik sebesar 46,5\%. Model persamaan struktural yang terbentuk adalah sebagai berikut:

$$
\eta=0,417 \xi_{2}+0,398 \xi_{3}
$$

\section{KESIMPULAN}

Berdasarkan analisis data maka dapat disimpulkan bahwa penerapan SEM-PLS untuk analisis kepuasan masyarakat terhadap pelayanan publik oleh Polda Kalimantan Barat didapatkan model persamaan yang terbentuk yaitu:

$$
\eta=0,417 \xi_{2}+0,398 \xi_{3}
$$

Pengaruh antara aspek pemeliharaan kamtibmas terhadap aspek kepercayaan masyarakat yaitu sebesar 0,417 yang artinya, semakin baik aspek pemeliharaan kamtibmas maka kepercayaan masyarakat akan meningkat sebesar 0,417 atau sebesar 41,7\%. Kemudian pengaruh antara aspek pelayanan publik terhadap aspek kepercayaan masyarakat yaitu sebesar 0,398 yang artinya, semakin baik aspek pelayanan publik maka kepercayaan masyarakat akan semakin meningkat sebesar 0,398 atau 39,8\%.

\section{UCAPAN TERIMAKASIH}

Ucapan terima kasih kepada semua pihak yang berperan dalam penyelesaian penelitian ini. Terkhusus ucapan terima kasih kepada Polda Kalimantan Barat yang telah mengizinkan peneliti untuk menggunakan data Survei Kepuasan Masyarakat terhadap Pelayanan Polda Kalimantan Barat. 


\section{DAFTAR PUSTAKA}

[1] Supranto, J. Analisis Multivariat: Arti dan Interpretas. Jakarta: Rineka Cipta; 2010.

[2] Sarwono, J. dan Narimawati, U. Membuat Skripsi, Tesis, dan Disertasi dengan Partial Least Square. Yogyakarta: C.V Andi Offset; 2015.

[3] Monecke, A., dan Leisch, F. SEM-PLS:Structural Equation Modeling Using Partial Least Square. Journal of Statistical Software. 2012.

[4] Wijanto, S. H. Structural Equation Modeling dengan Lisrel 8.8: Konsep dan Tutorial. Yogyakarta: Graha Ilmu; 2008.

[5] Abdillah, W. dan Jogiyanto. Partial Least Square (PLS) Alternatif Structural Equation Modeling (SEM) dalam Penelitian Bisnis. Yogyakarta: C.V Andi Offest; 2015.

[6] Siahaan, E. N. Hoyyi, A. dan Santoso, R. Analisis Kepuasan Masyarakat Terhadap Pelayanan Publik Menggunakan Pendekatan Partial Least Square. Jurnal Gaussian Vol. 6. 2017.

TITANIA AURELLIA $\quad$ : Jurusan Matematika FMIPA UNTAN, Pontianak nia110698@gmail.com

HENDRA PERDANA : Jurusan Matematika FMIPA UNTAN, Pontianak hendra.perdana@math.untan.ac.id 